\title{
O VIAJANTE DE OS SERTÕES
}

\author{
Gínia Maria Gomes
}

RESUMO: This essay analyses the intertextual relationship between $\boldsymbol{O} \boldsymbol{s}$ sertões and the travel chronicle written by the naturalistic travelers that explored the Brazilian countryside during the 19th century. Some similarities have been identified, such as the "otherness" of the individual traversing the back-country, the signs along the way, the traveler's observations on his obstacles, the perception of the melancholic back-country landscape, and, mainly, the scientific look, that enables us to approach the Euclides'narrative to those chronicles. The quotations from several naturalistic travelers proves that Euclides new these narratives. Thus, the presence of the features which are specific of travel chronicles in $\boldsymbol{O}$ s sertões evidences the relationship mentioned above and the importance of an analysis in the perspective of travels chronicles.

PALAVRAS-CHAVE: narrativa de viagem, viajante, olhar, alteridade.

\section{NARRATIVAS DE VIAGEM}

Os sertões, de Euclides da Cunha, ao longo de seus quase cem anos, têm sido abordado sob diversas perspectivas, o que a sua natureza híbrida permite. Este ensaio pretende destacar a presença das marcas da viagem transparentes no texto, notadamente na parte inicial - "A terra". Neste sentido, é interessante observar o diálogo que a narrativa euclidiana estabelece

Gínia Maria Gomes é professora de Literatura Brasileira do Instituto de Letras da UFRGS 
com os relatos de viagem do século XIX, principalmente com aqueles dos viajantes naturalistas. Em razão disso, torna-se necessário refletir sobre alguns elementos comuns dessas narrativas, principalmente os que estão presentes no texto de Euclides. Entre eles destacam-se: a condição de $o u$ tro daquele que percorre o sertão, as marcas do itinerário, as observações sobre os percalços da viagem, a percepção da uniformidade melancólica da paisagem sertaneja e, principalmente, o destaque do olhar de cientista, o que permite aproximar a narrativa euclidiana desses textos.

A condição de estrangeiros desses viajantes é fundamental. Em função dela destaca-se imediatamente a posição de outro que assumem: o mundo que percorrem é um outro para eles, enquanto eles mesmos são percebidos como outro entre os habitantes locais. Como europeus ${ }^{1}$, o ponto de referência é o mundo civilizado, a partir do qual ora percebem o atraso cultural, ora estabelecem aproximações e diferenças em relação à paisagem. Nesse sentido, circunstâncias banalizadas pelo cotidiano são redimensionadas, recebendo um enfoque imperceptível ao olhar local.

Outra marca importante dessas narrativas é a proximidade que mantém com o diário. Muitas vezes a referência da escrita em trânsito está presente na narrativa. Süssekind discute a questão:

Vale o vivido, se escrito. A experiência convertida em relato, diário. E diário que se deve escrever obrigatoriamente no calor da hora, que deve guardar as marcas do que se acabou de ver, do que se acabou de experimentar. Daí o reaproveitamento por Neuwied de imagem semelhante à das "memórias escritas com tinta do Brasil", de Léry: a das penas de araras recémcaçadas que se usam para escrever. Ou as inúmeras referências de Saint-Hilaire a essa escrita em trânsito, responsável pela maior exatidão das descriç̃es e observações relatadas, e por isso mesmo obrigatório aos viajantes-naturalistas. (SÜSSEKIND, 1990, p. 143).

Além das datas e itinerários, as referências às dificuldades da travessia estão constantemente sendo reiterados. Convém, no entanto, ressaltar que a constante alusão aos percalços da viagem não se constitui em particularidade exclusiva dos viajantes naturalistas. Ao contrário, esta é uma característica comum das narrativas de viagem em geral. Sendo um traço peculiar dos relatos de viagem, as travessias penosas constituem um dos topoi do gênero ${ }^{2}$. Para Spix e Martius, por exemplo, o sertão revela-se um percurso dificil, já

${ }^{1}$ Estamos pensando em Spix e Martius e em Neuwied, cujos relatos foram objeto de estudo em nossa Tese, intitulada A travessia de uma 'terra ignota': leitura de Os sertôes, de Euclides da Cunha.

${ }^{2}$ Analisando o diálogo dos narradores de ficção dos anos 30-40 do século passado, com as narrativas de viagem, Süssekind afirma: "Ressurge, então, alguns topoi da literatura de viagens: como as tempestades, as cenas de chegadas e lugares desconhecidos, as descrições de paisagens e tipos exóticos, os difíceis percursos por terra e por mar, e os muitos naufrágios que parecem deliciar particularmente os leitores" (SÜSSEKIND, 1990, p. 60). 
que o percorrem em pleno estio. Antes mesmo de adentrarem este espaço, são advertidos para os perigos de uma travessia nessas condições impróprias:

Eles acharam muito perigosa a viagem pelo sertão, nesta época do ano, e aconselharam-nos a desistir dela, porque as chuvas regulares de setembro a fevereiro tinham faltado e, por essa razão, a carência geral de água havia despovoado a estrada. (SPIX, MARTIUS, [19-], p. 219.)

As características recém discutidas - proximidade com o diário, as datas e os itinerários percorridos descritos, e ênfase às dificuldades encontradas na travessia - estendem-se a todas as narrativas de viagem, não sendo prerrogativa dos relatos escritos por viajantes naturalistas. No entanto, estes viajantes diferem dos demais. Com objetivos bem definidos, a forma de olhar os diferencia. Se também correm riscos ao se aventurarem por terras ignotas, procuram acercar-se do máximo de informações ${ }^{3}$, diminuindo, assim, a possibilidade de se defrontarem com circunstâncias desastrosas. Carregam cartas geográficas, tomam conhecimento dos relatos dos outros viajantes, se fazem acompanhar de guias locais e portam instrumentos de precisão, tanto para melhor se orientarem, como a bússola, quanto para melhor estudarem a natureza, como barômetros, eletrômetros e termômetros. Süssekind faz o levantamento dos principais interesses dos viajantes naturalistas:

Lições de botânica, inventários de costumes (cavalhadas, batuques, queimações de Judas, festas do Divino), lugares (vendas, fazendas, vilas, quilombos, igrejas, minas, aldeias), tipos (o tropeiro, o escravo rural e o urbano, o moleque, a mulher guardada a sete chaves, o fazendeiro, o gaúcho, o padre, o vendeiro, o índio), vistas (cachoeiras, matas cerradas, grutas, sertão, litoral): é esse "viajante prudente" que dá a ver e treina o modo de ver a paisagem brasileira de seus aprendizes locais. (SÜSSEKIND, 1990, p. 149-50)

Uma natureza útil é inventariada, descrita e classificada. Quando possível, ainda levam consigo os espécimes que conseguem apresar. Buscando sempre a verdade, apenas o que é comprovado in locu recebe estatuto de verdadeiro, porque em conformidade com a realidade examinada.

A reflexão sobre as narrativas de viagem permite afirmar que $O s$ sertões reproduz algumas de suas características. Por outro lado, a citação de vários viajantes naturalistas ${ }^{4}$ demonstra que Euclides teve acesso a es-

\footnotetext{
${ }^{3}$ Antes de se embrenharem no sertão, Spix e Martius procuram informações precisas sobre onde encontrar água: "e procuramos informações exatas sobre os pousos onde poderíamos encontrar água" (SPIX, MARTIUS, [19-], p. 219-20).

${ }^{4}$ Viajantes naturalistas citados em Os sertões: Eschwege (CUNHA, 1985, p. 93), Martius (CUNHA, 1985, p. 100 e 109), Fred. Hartt (CUNHA, 1985, p. 103), Agassiz (CUNHA, 1985, p. 103), Saint-Hilaire (CUNHA, 1985, p. 121 e 124), Humboldt (CUNHA, 1985, p. 130). Com exceção de Humboldt, proibido de entrar no Brasil, todos os outros percorreram as terras brasileiras e escreveram relatos sobre a viagem. Neuwied não é citado em Os sertões, mas seu nome é lembrado em um artigo de Contrastes e Confrontos, no qual refere-se ao fato de a exploração científica da terra ser delegada a estudiosos estrangeiros. (CUNHA, Euclides da, 1995. v. 1, p. 157).
} 
sas narrativas. Com Martius, por exemplo, esta circunstância fica evidente quando observa a Serra de Monte Santo. Esta se lhe afigura "com um perfil de todo oposto aos redondos contornos que lhe desenhou o ilustre Martius" (OS, p. 100). Desta forma, a inserção de especificidades próprias aos relatos de viagem, além da alusão a viajantes, evidenciam o diálogo e mostram a pertinência de uma análise do texto euclidiano à luz dessas narrativas.

\section{O OLHAR DO VIAJANTE}

Em Os sertões tem lugar uma voz impessoal, identificada ora pelo pronome "quem", ora por imagens genéricas como "forasteiro", "observador", "caminhante", "viandante" e "viajante". Essas imagens revelam a posição de alteridade assumida pelo narrador. No sertão, ele é o outro: é aquele que faz a travessia de um mundo desconhecido. Esta condição manifesta-se sobremaneira na expressão "as vistas inexpertas dos forasteiros" (CUNHA, 1985, p. 92). A perspectiva semântica de "forasteiro" - "estrangeiro, peregrino" (CUNHA, A., 1996, p. 364: forasteiro) - comporta o caráter de alteridade que caracteriza esse narrador ${ }^{5}$. Por outro lado, este aspecto está reforçado em "vistas inexpertas", cuja etimologia do adjetivo - do latim inexpertus, "não acostumado a" (FARIA, 1975, p. 493: inexpertus) - fortalece a experiência da diversidade que a viagem lhe proporciona. Nas outras imagens, embora a "estrangeiridade" esteja diluída, a categoria de outro é preservada: o seu olhar descobre uma terra nova, por onde ele transita buscando apreender suas múltiplas faces ${ }^{6}$.

A viagem tem no olhar atento do narrador a marca distintiva. A atividade escópica dissemina-se na narrativa, representada por meio dos substantivos "olhar" e "vistas" - instrumentos da visão - e dos verbos "ver", "divisar" e "observar". Estes verbos tornam evidente um olhar cuja principal qualidade é o desejo de conhecer, por isso a atenção com que se acerca do objeto $^{7}$. A natureza, transformando-se em objeto, é examinada por este

${ }^{5} \mathrm{O}$ narrador desdobra-se na personagem do viajante. Graças a este recurso, ele tem condições de perceber as nuanças que dão o tom deste olhar. Roland observa que "o narrador é aquele que traduz o suposto observador e o conduz em uma rota predeterminada. Sempre em busca dos sertões do norte. O narrador e o suposto viajante são, portanto, uma mesma instância separada por um artifício narrativo" (ROLAND, 1997, p. 178).

${ }^{6}$ Esta é a característica dos relatos dos viajantes estrangeiros. Na Carta de Pero Vaz de Caminha está presente este olhar que flagra no outro a alteridade. Observe-se o impacto diante das índias nuas: "Ali andavam entre eles três ou quatro moças, muito novas e muito gentis, com cabelos muito pretos e compridos, caídos pelas espáduas, e suas vergonhas tão altas e tão cerradinhas e tão limpas das cabeleiras que, de as muito bem olharmos, não tínhamos nenhuma vergonha." (CAMINHA, 1996, p. 82)

${ }^{7}$ Cardoso aponta para a diferença entre a visão, que "supõe um mundo pleno, inteiriço e maciço, e crê no seu acabamento e totalidade", e o olhar "que não descansa sobre a paisagem contínua de um espaço inteiramente articulado"; "o olho defronta constantemente limites, lacunas, divisões e alteridade, conforma-se a um espaço aberto, fragmentado e lacerado"; 
observador, a cada passo atraído pelos novos aspectos que se descortinam diante dele.

O confronto com a alteridade marca o périplo pelo sertão. Para este viajante, o sertão representa uma natureza completamente diferente daquela do litoral, de onde é oriundo. Deparar-se com a multiplicidade de imagens detectadas por seu olhar percuciente, dá lugar à "experiência do estranhamento" (CARDOSO, 1988, p. 359) que o novo lhe proporciona. Há um verdadeiro fascínio pela diversidade. São as imagens de uma natureza mutável, fragmentada, que se destacam para fazer sobressair as nuanças de seu "aspecto atormentado" (CUNHA, 1985, p. 103). Por isso, o estranhamento, marca da trajetória do viajante, revela-se ao confrontar a região inóspita do sertão, propiciando-lhe uma experiência singular. $\mathrm{O}$ impacto ocasionado pelo "agreste" (CUNHA, 1985, p. 99), transparece nas reações de surpresa apontadas pelo narrador. Este é flagrante quando, nos limites do deserto, percebe uma natureza modificada, diferente daquela antes vista: "ao atingir aquele ponto estaca surpreendido..." (CUNHA, 1985, p. 96) A brusca interrupção do movimento dimensiona a forte sensação provocada pela diversidade de uma paisagem que revela sua face desconhecida.

As expressões "Terra ignota" (CUNHA, 1985, p. 96) e "estranho território" (CUNHA, 1985, p. 97), utilizadas a seguir, se marcam a ruptura com a familiaridade, também demonstram a profunda impressão desta terra estranha sobre o viajante. Ainda corroboram com este enfoque afirmações do tipo "não se surpreende a princípio" (CUNHA, 1985, p. 98) ou "É uma paragem impressionadora" (CUNHA, 1985, p. 100); ambas descobrem um olhar afetado pelo objeto. O estranhamento diante dessa natureza se revela no aflorar dessas impressões de surpresa.

O impacto diante do desconhecido e o desejo de abarcá-lo induz o sujeito a fazer constante uso da analogia ${ }^{8}$, recurso marcante na tentativa de apreender esta "terra ignota". Ao ver, o viajante, desejoso de fazer uma descrição completa do objeto, traz para o "agreste" um arsenal de imagens que pertencem ao mundo civilizado, algumas, inclusive, específicas do

é a "descontinuidade e o inacabamento do mundo que o atraem" (CARDOSO, 1988, p 349). Em "A terra, no entanto, estes limites não se sustentam, porque o "ver", quando empregado, mostra a atividade do sujeito, em detrimento da passividade, estando, por isso, no mesmo plano dos outros verbos.

${ }^{8}$ Recorrendo à analogia o viajante-narrador consegue amenizar o estranhamento que caracteriza o encontro com o novo. Neste sentido, o texto de Euclides aproxima-se da "Carta" de Caminha: "O Outro, diverso e múltiplo, é descrito a partir de categorias sólitas; tentando redizer o antigo para dizer o novo, Caminha vai recorrer frequentemente à analogia - num esquema de correspondência de semelhanças e dissemelhanças entre o desconhecido e o já conhecido - como forma de preencher um vazio referencial que fundamenta o encontro." (FERNANDES, 1977, p. 147-148). 
litora $l^{9}$. Frente a uma determinada "paragem", depois de esgotar os recursos de linguagem no seu delineamento, deixa-se levar pelas impressões: "As mesmas assomadas gnáissicas caprichosamente cindidas em planos quase geométricos, à maneira de silhares, que surgem em numerosos pontos, dando às vezes, a ilusão de encontrar-se, de repente, naqueles ermos vazios, majestosas ruinarias de castelos" (CUNHA, 1985, p. 101).

A comparação dá-lhe uma imagem com delineamentos mais nítidos. Em outro momento, quando o cenário se transforma e uma "natureza torturada" se apresenta ao viajante, ela é percebida através da evocação da imagem marítima: "tem a impressão persistente de calcar o fundo recémsublevado de um mar extinto, tendo ainda esteriotipada naquelas camadas rígidas a agitação das ondas e das voragens..." (CUNHA, 1985, p. 103)

Reconhecer no objeto imagens que não lhe concernem, reforça a atividade do sujeito, pondo em foco o olhar criativo do viajante: ao ver um objeto que foge à determinação, ele busca compreendê-lo; para isto o define com a linguagem de seu próprio mundo. Tanto a surpresa diante da "terra ignota", quanto a tentativa de apreendê-la, recorrendo ao arsenal imagético alheio ao sertão, revelam a "experiência de estranhamento" vivenciada pelo viajante, instaurada no confronto com a alteridade ${ }^{10}$.

Outro traço distintivo das narrativas de viagem constitui-se na sinalização dos itinerários. Observou-se antes, nesses relatos, a indicação dos lugares por onde passavam, ficando delimitada a rota da viagem. Em $O s$ sertões, o recurso só recebe uma atenção mais acurada ao adentrar a região denominada "Terra ignota", cujos limites são fixados pelos rios São Francisco e Itapicuruaçu: "Demarca-o de uma banda abrangendo dous quadrantes, em semicírculo o rio São Francisco, e de outra, encurvando também para sudeste, numa normal à direção primitiva, o curso flexuoso do Itapicuruaçu." (CUNHA, 1985, p. 96)

Deste momento em diante, vários locais são mencionados - Serrinha, Vila Nova da Rainha, Juazeiro, Cansação, Quirinquinquá, Caldeirão, Serra do Monte Santo, entre outros -, seguindo-se, às vezes, alguns comentários, em geral sobre o solo. Como nesta parte de Os sertões o interesse exclusivo centra-se na terra, outras observações não seriam pertinentes,

${ }^{9}$ Esta é a marca dos viajantes. Eles olham para o desconhecido através da bagagem cultural que lhes é inerente: "estes escritos reflectem sempre um conhecimento filtrado pelo prisma cultural que representa o autor e onde a tradição e a novidade, a teoria e a experiência, o imaginário e o sensível, o subjectivo e o objectivo se conjugam numa enorme complexidade tentando, por vezes, explicar o novo à luz de velhos conceitos." (PIMENTEL, SANTOS, 1977, p. 217).

${ }^{10}$ Instaura-se na viagem uma "situação de comunicação": "le voyageur-narrateur doit nécessairement affronter la tension entre l'expérience méta-organique de l'espace étranger et les caractéristiques immanentes de ce même espace qu'il ne peut pénetrer qu'approximativement." (KRYSINSKI, 1997, p. 137-8).

138 
porque extrapolariam as propostas do autor. Uma maior precisão dos locais por onde o viajante passa é substituída por verbos de movimento e por modalizadores de espaço. Estes recursos sinalizam o itinerário, o que, nas narrativas de viagem é feito, principalmente, por meio da identificação dos locais. Verbos que indiciam deslocamento - "transmontar", "galgar", "atravessar", "transpor", "caminhar" - se repetem na narrativa. Os modalizadores de espaço também atestam o movimento do viajante. Entre eles, se sobressaem: "aqui", "ali", "adiante", "desse ponto em diante", "deste lugar em diante", "mais longe" e "ao longe". Além disso, o reiterado emprego do vocábulo "travessia" confirmam este movimento. A opção por estes recursos é de extrema importância, porque o texto ganha em literariedade o que perde em precisão. Recorrendo a eles, torna evidente as características da viagem. Nela, o viajante a todo o momento atraído por uma natureza em constante mutação, não se exime de mostrar as várias faces que seu olhar divisa.

O deserto, com seus limites delineados pelos rios é o cenário que se desvela ao viajante. Dar continuidade à viagem significa dispor-se a realizar a travessia desta terra imune ao traçado geográfico - "fantasia de cartógrafo" (CUNHA, 1985, p. 96) -, aos colonizadores, que não penetraram no "estranho território" (CUNHA, 1985, p. 118) e às investidas das bandeiras, cujos aventureiros deixaram intacta. Mais adiante, refletindo sobre o clima, o narrador afirma que nenhum "pioneiro da ciência" permanecera naquele espaço "em prazo suficiente para o definir" (CUNHA, 1985, p. 109). Nem mesmo Martius fora exitoso nesta tarefa porque, com o objetivo de observar o "aerólito", não se concentrara o bastante no estudo da terra. Os outros, que porventura cruzaram "aquele sertão" (CUNHA, 1985, p. 109) "palmilharam, ferretoados da canícula, as mesmas trilhas rápidas" (CUNHA, 1985, p. 109), que este viajante pretende atravessar.

Ao realizar a "travessia das veredas sertanejas" (CUNHA, 1985, p. 118), o olhar, atraído pelo "facies excepcional e selvagem" (CUNHA, 1985, p. 96) da terra, observa suas transformações: as matas que pouco a pouco "empobrecem" até se extinguirem; seus "rebentos esparsos" permanecem para caracterizarem a flora dominante "nas planuras desnudas dos campos"; "arbustos flexuosos entressachados de bromélias rubras" (CUNHA, 1985, p. 97). A continuidade da travessia representa afrontar os novos contornos de um quadro que recém começava a se esboçar. Embrenhar-se naquele "sertão inóspito", em "pleno agreste" significa confrontar "lugares que se vão tornando crescentemente áridos", "areais excicados", que remoram a marcha; compondo este cenário, o olhar tem diante de si a monotonia e uniformidade do "pardo requeimado das caatingas" (CUNHA, 1985, p. 99). Nesse momento o viajante se encontra em pleno deserto. 
Estas primeiras imagens do sertão-deserto deixam entrever a ação corrosiva do sol: torna o solo árido e a flora "requeimada". Esta representação do deserto está em sintonia com o imaginário cristão; nesta perspectiva, pensá-lo como espaço geográfico é figurá-lo como uma terra onde "a água [...] é rara, como no jardim do paraíso antes que chovesse, a vegetação é miúda, a habitação impossível" (LÉON-DUFOUR, 1992, p. 215: deserto.).

As imagens do deserto se desdobram no transcorrer da viagem. Percebe-se, nela, o movimento de embrenhar-se no sertão: "e alcançando-o, e transpondo-o, entra-se, afinal, em cheio, no sertão adusto..." (CUNHA, 1985, p. 100). O sertão representa o novo para o viajante; por isso a necessidade de reiterar que "afinal" se encontra no "sertão adusto". Sabe-se, no entanto, que, ao iniciar a viagem, o viajante já percebe o caráter desértico da paisagem. Talvez o desconhecimento do trajeto viabilize a constante surpresa diante de uma natureza mutável, que se mostra, a cada passo, sob um ângulo diverso. Agora, desvela-se "o aspecto atormentado das paisagens", que aflora "no enterroado do chão, no desmantelo dos cerros quase desnudos, no contorcido dos leitos secos dos ribeirões efêmeros, no constrito das gargantas e no quase convulsivo de uma flora decídua embaralhada em esgalhos" (CUNHA, 1985, p. 101).

Sem dúvida, as imagens acrescentam novos elementos e revelam o confronto do viajante com uma nova paragem; esta, ao lado das anteriores, representa um quadro diverso e complementar na figuração do deserto.

O sertão-deserto torna penosa a travessia. As referências a essas dificuldades, decorrentes do caráter desértico da paisagem, são reiteradas na narrativa. Antes mesmo de iniciar o périplo pelo sertão "ignoto" (CUNHA, 1985, p. 97), ele refere-se aos diversos "povoadores", que sempre procuraram contornar esta terra, "subtraindo-se a uma travessia torturante" (CUNHA, 1985, p. 98). No percurso, "as cacimbas e os caldeirões" (CUNHA, 1985, p. 99) atenuam as agruras da "viagem penosíssima" (CUNHA, 1985, p. 99). Logo adiante são os "areais exsicados" (CUNHA, 1985, p. 99) que representam obstáculo: "o viajante mais rápido tem a sensação da imobilidade" (CUNHA, 1985, p. 99). Prosseguindo, depara-se com um solo acidentado pelo efeito das erosões: "tangendiando-se em quinas de rebordos cortantes, em pontas e duríssimos estrepes que impossibilitam as marchas" (CUNHA, 1985, p. 102).

Uma flora característica do sertão completa o cenário da representação do deserto: a caatinga. O viajante, outra vez, encontra-se diante de uma quadro distintivo: a amplidão do horizonte, proporcionada pelas "estepes nuas" dá lugar à completa limitação do olhar, cerceado por uma flora 
que o "afoga" e "abrevia-lhe o olhar" (CUNHA, 1985, p. 118). Os obstáculos se intensificam: "Então, a travessia das veredas sertanejas é mais exaustiva que o de uma estepe nua" (CUNHA, 1985, p. 118). O acréscimo de dificuldades no percurso aponta para o caráter de provação vinculado ao imaginário do deserto: o povo de Israel deve "atravessar o deserto para viver na Terra prometida" (LÉON-DUFOUR, 1992, p. 215: deserto). Também este viajante deve percorrê-lo para, só então, vislumbrar a "apoteose" do sertão (CUNHA, 1985, p. 125).

A caatinga torna-se para o viajante um obstáculo quase intransponível: "agride-o e estonteia-o; enlaça-o na trama epinescente e não o atrai; repulsa-o com as folhas urticantes, com o espinho, com os gravetos estalados em lanças" (CUNHA, 1985, p. 118). Defendendo-se à invasão, converte a travessia em verdadeira provação. O comentário sobre estas dificuldades é logo substituído pela contemplação da flora, que, no conjunto, afigura-se uma espécie única. Olha a caatinga e, mais uma vez, vê-se diante de uma "flora agonizante" (CUNHA, 1985, p. 118) sob os efeitos devastadores do sol: capta a luta daquela para fugir a ação causticante dos raios solares.

Em Os Sertões a travessia do deserto alinha-se à perspectiva do imaginário cristão ${ }^{11}$ : a provação tem sua recompensa na visão do paraíso. Em dois momentos as imagens paradisíacas se impõem: o primeiro se realiza quando o viajante, no final do percurso, depois de confrontar inúmeros obstáculos, encontra-se no "topo da Favela"; o outro se apresenta ao descobrir um sertão transmutado pela chuva.

"Galgava o topo da Favela" (CUNHA, 1985, p. 108). Aqui, no cimo da montanha, o olhar defronta um novo cenário, "antítese do que vira" (CUNHA, 1985, p. 108). Embora, na realidade, ainda predominem os mesmos aspectos, reunidos e, talvez pela distância, transformam a paisagem, abarcada "de um lance" (CUNHA, 1985, p. 108). Então, o viajante "quase compreendia que os matutos crendeiros, de imaginativa ingênua, acreditassem que ali era o céu..." (CUNHA, 1985, p. 108). A primeira imagem de Canudos, termo da viagem, é a de paraíso. A cidadela se encontra entre montanhas - "Em roda uma elipse majestosa de montanhas..." (CUNHA, 1985, p. 108) - e só é divisada ao atingir o topo de uma delas. É significativo entrever o paraíso no alto da Favela, depois de o viajante se ter submetido a uma travessia dificultada por inúmeros obstáculos. Este fato encontra-se plenamente justificado no simbolismo da montanha, asso-

\footnotetext{
11"Deus não chamou Israel a viver no deserto, mas a atravessar o deserto para viver na terra prometida." (LÉON-DUFOUR, 1992, p. 215: deserto)
} 
ciado à altura e ao centro ${ }^{12}$. Na tradição bíblica ela ocupa um lugar privilegiado: "se revestem de um valor sagrado e simbolizam em seguida uma hierofania" (CHEVALIER, GHEERBRANT, 1990, p. 616: montanha). Sérgio Buarque de Holanda também discute o papel da montanha na construção da imagem do paraíso. Afirma que, no imaginário bíblico ela "se apresenta melhor sob o aspecto de uma altíssima e invencível escarpa" (HOLANDA, 1994, p. 161), que dificultaria o acesso ao paraíso. A trajetória do viajante se alinha à perspectiva da visão cristã: só se defronta com o paraíso depois de ter percorrido o deserto, enfrentando obstáculos que remoraram a caminhada. No final da jornada, no "alto da Favela", o conjunto da paisagem lhe permite "quase" compreender que "ali era o céu".

O paraíso revela-se inicialmente como espaço geográfico. No término da travessia, o viajante, extasiado com o que vê, lembra que, para os "matutos crendeiros", "ali era o céu". A visão do paraíso novamente se descobre depois de um período de chuvas. Antes, ele representava um espaço físico determinado; agora, ele se dá no tempo, "no empardecer de uma tarde qualquer de março" (CUNHA, 1985, p. 125). As chuvas, fertilizando a terra, produzem "uma mutação de apoteose" (CUNHA, 1985, p. 125). Como agente fecundador do solo" (CHEVALIER, GHEERBRANT, 1990, p. 235: chuva.) são responsáveis pela transformação do cenário. É a metamorfose da natureza. A flora apresenta sua face exuberante, tendo ocorrido a "mutação de apoteose"13:

Sobre o solo que as amarílis atapetam, ressurge triunfalmente a flora tropical.

É uma mutação de apoteose.

Os mulungus rotundos, à borda das cacimbas cheias, estadeiam a púrpura das largas flores vermelhas, sem esperar pelas folhas; as caraíbas e baraúnas altas refrondescem à margem dos ribeirões refertos; ramalham, ressoantes, os marizeiros esgalhados, à passagem das virações suaves; assomam, vivazes,

\footnotetext{
${ }^{12}$ “O simbolismo da montanha é múltiplo: prende-se à altura e ao centro. Na medida em que ela é alta, vertical, elevada, próxima do céu, ela participa do simbolismo da transcendência; na medida em que é o centro das hierarquias atmosféricas e de numerosas teofanias, participa do simbolismo da manifestação." (CHEVALIER, GUEERBRANT, 1990, p. 616: montanha).

${ }^{13}$ A "apoteose" do sertão dimensiona a grandiosidade da natureza, que se oferece como espetáculo. Segundo Faria a "apoteose" "era o nome que se dava ao último quadro das revistas de ano, um gênero teatral que foi bastante apreciado no Brasil do final do século XIX. A característica principal da apoteose era a sua grandiosidade, o fato de ser um espetáculo para os olhos. Geralmente era um quadro estático, criado pelo cenógrafo para exaltar uma idéia contida na peça, uma per-sonalidade, um acontecimento, etc. Na revista $O$ homem, por exemplo, Artur Azevedo termina o penúltimo quadro e anuncia a "mutação" para a "apoteose do amor". O que vai aparecer no palco já não é sua responsabilidade e depende unicamente do cenógrafo. Quando Euclides escreve "mutação de apoteose" ele está, portanto, exaltando o espetáculo que a natureza nordestina oferece aos seus olhos, como se estivesse num teatro, como se a mutação da terra seca em terra fértil ocorresse por um passe de mágica ou pela engenhosidade de um cenógrafo." (FARIA, João Roberto, 1998, p. 26).
} 


\begin{abstract}
amortecendo as truncaduras das quebradas as quixabeiras de folhas pequeninas e frutos que lembram contas de ônix; mais virentes, adensam-se os icozeiros pelas várzeas, sob o ondular festivo das copas dos ouricuris: ondeiam, móveis, avivando a paisagem, acamando-se nos plainos, arredondando as encostas, as moitas floridas do alecrim-dos-tabuleiros, de caules finos e flexíveis; as umburanas perfumam os ares, filtrando-os nas frondes enfolhadas, e - dominando a revivescência geral não já pela altura senão pelo gracioso do porte, os umbuzeiros alevantam dous metros sobre o chão, irradiantes em círculo, os galhos numerosos. (CUNHA, 1985, p. 125)
\end{abstract}

A natureza toda floresce. O olhar capta a singularidade das diversas espécies; cada uma aparece com sua fisionomia espetacular. O conjunto forma o "cenário deslumbrante" e enseja a conclusão: "E o sertão é um paraíso" (CUNHA, 1985, p. 127). A representação do paraíso sertanejo dá ênfase à fertilidade da terra e à riqueza da flora. Estes são motivos recorrentes na figuração do paraíso, geralmente retratado como um jardim "cheio de árvores frutíferas, de plantas odoríferas, de riachos..." (SEJESTANI, Abuya 'qu' apud CHEVALIER, GHEERBRANT, 1990, p.512: jardim). No Gênesis, Adão "cultivava o jardim"14. O cenário flagrado pelo viajante reitera a tradição bíblica: reproduz as imagens consagradas do jardim do Éden.

Além da flora, o viajante percebe a fauna "resistente das caatingas": são os "caititus esquivos", os "queixadas de canela ruiva" as "emas velocíssimas", as "seriemas de vozes lamentosas", as "sericóias vibrantes", as "suçuaranas", os "mocós espertos" e ainda os "veados ariscos" e os "novilhos desgarrados" (CUNHA, 1985, p. 127). Ao lado desta fauna estritamente ligada à terra, sobrevivente das caatingas, tem lugar os pássaros: "Num tumultuar de desencontrados vôos passam, em bandos, as pombas bravas que remigram, e rolam as turbas turbulentas das maritacas estridentes..." (CUNHA, 1985, p. 127)

Associados ao mundo celeste, simbolizam a espiritualização (CIRLOT, 1984, p. 446: pássaro). São eles que completam o quadro paradisíaco das "manhãs sem par" (CUNHA, 1985, p. 127). Todos são vistos em sua singularidade, naquilo que os caracteriza e os faz diferentes dos demais. Vivem em liberdade, por isto a possibilidade de exercitarem as qualidades distintivas. A mesma liberdade encontram os animais do jardim do Éden (CHEVALIER, GHEERBRANT, 1990, p. 685: paraíso).

Resta ainda examinar dois motivos geralmente presentes na representação do Éden: os rios e o clima ameno. Embora não recebam a mesma ênfase da flora e da fauna, os rios são mencionados e compõem o quadro

14“'Iahweh Deus tomou o homem e o colocou no jardim de Éden para o cultivar e guardar." (Gênesis 2, 15. BÍBLIA de Jerusalém, 1991). 
do Éden sertanejo. Não mais os quatro rios do Gênesis, mas a breve afirmação: "Os vales secos fazem-se rios" (CUNHA, 1985, p. 129). Quanto ao bom clima, já revelado em "manhãs sem par", pode também ser inferido de "Cai a temperatura. Com o desaparecer das soalheiras anula-se a secura anormal dos ares" (CUNHA, 1985, p. 129). O cenário primaveril se confirma na ênfase às várias tonalidades de que se reveste a paisagem: "a transparência do espaço salienta as linhas mais ligeiras, em todas as variantes da forma e da cor" (CUNHA, 1985, p. 129).

A perspectiva do sertão paradisíaco afasta o texto euclidiano das narrativas dos viajantes naturalistas. Eles estavam longe de perceber esta terra castigada pela ação corrosiva do sol e pelas secas como um lugar paradisíaco. Ao contrário, procuravam apresentar os problemas oriundos de semelhante conjuntura. Este é o caso da completa destruição das roças de feijão, milho e mandioca em Vila Nova da Rainha, observados por Spix e Martius (SPIX, MARTIUS, [19-], p. 230). Por outro lado, estes mesmos viajantes, ao constatarem a extrema fertilidade da terra, que se transforma imediatamente com chuvas esporádicas, procuram explicar cientificamente tal circunstância (SPIX, MARTIUS, [19-], p. 221). Euclides, abstraindo-se dessas explicações, vendo o sertão como um espaço paradisíaco, confere ao texto maior densidade, além de alinhá-lo a uma tradição já consagrada.

Ao figurar o sertão como um paraíso, o autor inscreve-o na tópica do locus amoenus, discutida por Curtius (1996, p. 254-258). Segundo o autor, este topos "constitui o motivo principal de toda descrição da Natureza" (CURTIUS, 1996, p. 254). Destaca a presença da árvore, da campina, da fonte ou regato, como principais elementos que compõem essa natureza. Além deles, ainda ressalta "o canto dos pássaros, umas flores e, quando muito, o sopro da brisa" (CURTIUS, 1996, p. 254) como aspectos variáveis. Na poesia latina da Antigüidade, a recorrência ao locus amoenus pontua as descrições de cenário. Na Idade Média, esse recurso passa a representar um "requisito poético" (CURTIUS, 1996, p. 256). É interessante o alargamento que sofre, nos fins do século XII, quando se desdobra nas descrições do "paraíso terrestre" (CURTIUS, 1996, p. 256). Nesse momento, alguns elementos novos the são acrescentados: ora é uma "planície circular" (CURTIUS, 1996, p. 256), ora é um lugar das "delícias" - onde se encontram "especiarias, bálsamo, mel, vinho, cedro, abelhas" (CURTIUS, 1996, p. 257) -, ora o "bosque aprazível é a rosa do mundo" (CURTIUS, 1996, p. 257).

Na literatura brasileira, este topos desdobra-se no tema do sertão paradisíaco, tendo uma tradição consolidada. Iniciando-se no Romantis- 
mo, está presente em poetas ${ }^{15}$ e romancistas da época. É, sobretudo, nos romances que o sertão terá enfoque especial. Cristóvão faz algumas considerações sobre os que se ocupam da temática (CRISTÓVÃO, 1993-1994, p. 44-48). $O$ Ermitão de Muquém, de Bernardo Guimarães (1952), e $O$ sertanejo, de José de Alencar (1962), são os romances mais representativos da imagem do "sertão florido" (CRISTÓVÃO,1993-1994, p. 46). A narrativa alencariana pode ser considerada a "obra-prima síntese do sertão romântico e tranqüilo, onde a paz e a felicidade se dão as mãos para tanto o senhor como o servo serem felizes" (CRISTÓVÃO,1993-1994, p. 44). Nela, o sertão paradisíaco é mostrado em toda a sua plenitude. Esta tradição não pára no Romantismo. Textos em que a visão realista predomina a mantém. Este é o caso de O cabeleira, de Franklin de Oliveira (1969), e de Dona Guidinha do Poço, de Manuel de Oliveira Paiva (1965). Esta tradição, que sobrevive no Realismo, embora já "misturada" com imagens "menos repousantes e agradáveis", (...) "vem até os nossos dias" (CRISTÓVÃO,1993-1994, p. 47).

Os principais motivos edênicos, pertencentes a uma larga tradição, não escapam ao olhar do viajante: uma flora abundante, com árvores frutíferas e belas flores; uma fauna rica em animais selvagens, entre as quais não falta a serpente; abundância de água, que fertiliza a terra, na qual tudo floresce espontaneamente; e, finalmente, o clima primaveril, atenuado pelas chuvas.

Enquanto a visão da natureza paradisíaca afasta o texto de Euclides das narrativas dos viajantes naturalistas, a percepção da uniformidade, monotonia e melancolia da paisagem o aproxima desses relatos. Esta perspectiva é recorrente no olhar do viajante. Certamente, o "sertão adusto", com sua vegetação uniforme, já está dela impregnado. Em várias ocasiões a natureza é entrevista sob este prisma. Ao adentrar o "agreste", as peculiaridades do "sertão inóspito" (CUNHA, 1985, p. 99) se impõem: "Galgase uma ondulação qualquer - e ele se desvenda ou se deixa adivinhar, ao longe, no quadro tristonho de um horizonte monótono em que se esbate, uniforme, sem um traço diversamente colorido, o pardo requeimado das caatingas" (CUNHA, 1985, p. 99).

"Quadro tristonho", "horizonte monótono" e "uniforme" são os traços captados pelo viajante. Nas caatingas, "requeimadas" pelo sol causticante, a diversidade não tem espaço, do que se infere a melancolia de uma paisagem dominada pela uniformidade. Parece que este é o quadro

\footnotetext{
${ }^{15}$ Entre os poetas, cujos poemas reiteram a temática, salientam-se Álvares de Azevedo, Casimiro de Abreu, Junqueira Freire e Castro Alves. Todos eles "celebram a natureza florida e os amores que eram o seu prolongamento natural". (CRISTÓVÃO, 1993-94, p. 44).
} 
preponderante, o qual transparece em "uma ondulação qualquer". Afigurase que independente da trajetória, o viajante terá diante de si sempre o mesmo quadro. Ao vislumbrar o "oásis" este enfoque é evidente. Apesar do caráter positivo a que se vincula, o viajante vê apenas seu aspecto negativo, quando os traços melancólicos da paisagem se impõem: "Verdadeiros oásis, têm contudo, não raro, um aspecto lúgubre: localizados em depressões entre colinas nuas, envoltas pelos mandacarus despidos e tristes, como espectros de árvores." (CUNHA, 1985, p. 99)

Muitas vezes, a feição melancólica é percebida nas ruínas dos casebres, que constituem mais uma nota na composição do quadro: "em ruínas outras; agravando todas, no aspecto paupérrimo, o traço melancólico das paisagens..." (CUNHA, 1985, p. 100)

Quando a uniformidade da paisagem é quebrada por alguma flor, o viajante é atraído por tal circunstância inusitada. Isto apenas comprova que a melancolia, evolando-se da natureza, é a tônica dominante. Observando as diversas espécies, o olhar flagra "as palmatórias-do-inferno, opúntias de palmas diminutas, diabolicamente eriçadas de espinhos, - com o vivo carmim das cochonilhas que alimentam; orladas de flores rutilantes, quebrando alacremente a tristeza solene das paisagens..." (CUNHA, 1985, p. 124)

Entretanto, em alguns momentos ela, afetando-o sobremaneira, faz emergir a emoção de forma ainda mais contundente: a dor que a visão do objeto lhe proporciona está explicitada na afirmação "Daí a impressão dolorosa que nos domina ao atravessarmos aquele ignoto trecho do sertão.” (CUNHA, 1985, p. 105)

Esses traços do sertão-deserto, que tem a caatinga como flora prevalecente, foram percebidos por Spix e Martius e por Neuwied. Igualmente para estes viajantes a uniformidade, monotonia e melancolia da natureza foram as impressões dominantes. Ora, tal percepção é procedente, porque todos eles fazem a travessia em período de seca, quando a flora apresentase "requeimada" pela intensidade dos raios solares.

Um outro aspecto, que também contribui para aproximar Os sertões das narrativas de viagem, é o olhar do cientista, observador atento, que procura identificar, classificar, descrever, enfim, fazer da natureza objeto de estudo. No percurso, o solo, o clima, a flora e a fauna são considerados. A cada passo, o viajante detém-se para o exame da natureza, registrando aquilo que se apresenta ao seu campo de visão. No entanto, no texto de Euclides, ao olhar arguto do cientista, que perscruta a paisagem circundante, sobrepõe-se o do poeta. Desta forma, quanto mais próximo o diálogo com os viajantes naturalistas, tanto mais deles se afasta, porque, ao apresentar cientificamente os dados, igualmente extrapola esta perspectiva, quando o 
poeta ou está lado a lado com o cientista, ou o domina completamente. Em várias circunstâncias se destacam descrições em que o autor consegue a aliança entre "ciência e arte"16; em outras, o olhar científico é sobrepujado pelo olhar fantasmático. Por essa razão, a literariedade do texto revela-se sua marca distintiva.

Percorrendo a caatinga, o viajante é logo atraído pelos diversos vegetais que a constituem. $\mathrm{O}$ seu olhar se detém nas várias espécies, cuja sobrevivência à falta de água e ao sol causticante é surpreendente. É então que o cientista assume o seu posto: faz o inventário da natureza que, submetida ao seu escrutínio, é logo classificada e descrita. O inventário igualmente contempla os vegetais ainda não catalogados por cientistas; este é o caso das "favelas":

As favelas, anônimas ainda na ciência - ignoradas dos sábios, conhecidas demais pelos tabaréus - talvez um futuro gênero cauterium das leguminosas, têm, nas folhas de células alongadas em vilosidades, notáveis aprestos de condensação, absorção e defesa. Por um lado, a sua epiderme ao resfriar-se, à noite, muito abaixo da temperatura do ar, provoca, a despeito da secura deste, breves precipitações de orvalho; por outro, a mão que a toca, toca uma chapa incandescente de ardência inaturável. (CUNHA, 1985, p. 121)

Mesmo sendo um vegetal "anônimo ainda na ciência", o narradorviajante não se exime à tentativa de catalogá-lo, ao que se segue uma descrição criteriosa, sem esquecer de suas especificidades: "ao resfriar-se [...] provoca [...] precipitações de orvalho", embora conserve calor "inaturável".

Procede da mesma forma com todos os espécimes com que se depara. Entre outros, estão os "cajueiros anões" (CUNHA, 1985, p. 121), os "mandacarus" (CUNHA, 1985, p. 122), os "xiquexiques" (CUNHA, 1985, p. 122) e as "palmatórias-do-inferno" (CUNHA, 1985, p. 124). Caso algum dos vegetais que encontra já tenha sido classificado por outro viajante naturalista, o narrador menciona o fato. Isto ocore com as "nopáleas e cactos", que "entram na categoria das fontes vegetais, de Saint-Hilaire" (CUNHA, 1985, p. 121). O mesmo sucede com a "caatanduva, mato doente", que corresponde à "silva aestu aphylla, a silva horrida, de Martius" (CUNHA, 1985, p. 124).

Examinando os "cabeças-de-frade", o olhar do cientista conjugase ao olhar do poeta. Neste sentido, a descrição é exemplar, porque, nela, o narrador exibe a preconizada aliança entre "ciência e arte":

Têm como sócios inseparáveis neste habitat, que as próprias orquídeas evitam, os cabeças-de-frade, deselegantes e mons-

${ }^{16}$ Para Euclides a representação artística estaria alicerçada na ciência: "qualquer trabalho literário se distinguirá dos estritamente científicos, apenas, por uma síntese mais delicada, excluída apenas a avidez característica das análises e das experiências" (GALVÃO, GALOTTI, 1997, p. 144). 
truosos melocactos de forma elipsoidal, acanalada, de gomos espinescentes, convergindo-lhes no vértice superior formado por uma flor única, intensamente rubra. Aparecem, de modo inexplicável, sobre a pedra nua, dando, realmente, no tamanho, na conformação, no modo porque se espalham, a imagem singular de cabeças decepadas e sanguinolentas jogadas por ali, a esmo, numa desordem trágica. E que estreitíssima frincha lhes permitiu insinuar, através da rocha, a raiz longa e capilar até a parte inferior onde acaso existam, livres de evaporação, uns restos de umidade. (CUNHA, 1985, p. 124)

Identifica, cataloga e descreve o espécime, para, depois, extrapolando a perspectiva meramente científica, conferir-lhe o estatuto de imagem, quando as flores "intensamente rubra(s)" do vegetal passam a representar "cabeças decepadas e sanguinolentas", imagem antecipatória dos acontecimentos vindouros. Por outro lado, há, no interior da descrição científica, um ritmo especial, o qual permite converter o trecho em uma forma versificada. Augusto de Campos percebe a cadência estruturada dos versos:

Cabeças-de-frade

... sócios incomparáveis neste habitat

que as próprias orquídeas evitam,

os cabeças-de-frade,

deselegantes e monstruosos

melocactos de forma elipsoidal, acanalada, de gomos espinescentes, convergindo-lhes no vértice superior formado por uma flor única,

intensamente rubra.

Aparecem, de modo inexplicável,

sobre a pedra nua,

dando, realmente, no tamanho,

na conformação, no

modo por que se espalham,

a imagem singular de

cabeças decepadas e sanguinolentas,

jogadas por ali, a esmo,

numa desordem trágica. (CAMPOS, 1997, p. 36)

A forma versificada põe em evidência o caráter artístico do trecho. Converter o vegetal em imagem e descrevê-lo plasmado a um acento rítmico são elementos essenciais para a irrupção do olhar do poeta. O olhar do cientista, no entanto, não desaparece. Sem abdicar de suas funções, recorre a termos científicos para delinear o seu objeto. Neste sentido, mantém uma perfeita sintonia com as narrativas dos viajantes naturalistas, cujos narradores procuravam fazer uma descrição minuciosa do objeto, sendo este examinado com atenção.

A reflexão sobre a secura do clima revela-se mais uma página em que o "consórcio da ciência e da arte" é exitoso. Enquanto Spix e Martius discorrem sobre as especificidades de tal clima, ressaltando a impossibi- 
lidade de as matérias orgânicas se decomporem (SPIX, MARTIUS,[19], p. 220), Euclides mostra esta particularidade através da criação de uma cena. O narrador-viajante, percorrendo as imediações do arraial, depara-se com um soldado morto. A descrição do cenário, com a aparência de "um velho jardim em abandono" (CUNHA, 1985, p. 112), prepara o quadro. O olhar arguto observa os vários ângulos da paisagem, completada pelo dimensão temporal: é ao pôr-do-sol que o episódio tem lugar. Só então é mostrada a figura humana:

O sol poente desatava, longa, a sua sombra pelo chão e protegido por ela - braços largamente abertos, face voltada para os céus - um soldado descansava.

Descansava... havia três meses.

Morrera no assalto de 18 de julho. [...] O destino que o removera do lar desprotegido fizera-lhe afinal uma concessão: livrara-o da promiscuidade lúgubre de um fosso repugnante; e deixara-o ali há três meses - braços largamente abertos, rosto voltado para os céus, para os sóis ardentes, para os luares claros, para as estrelas fulgurantes... (CUNHA, 1985, p. 112)

Também este segmento é transmodalizado em poema por Augusto de Campos:

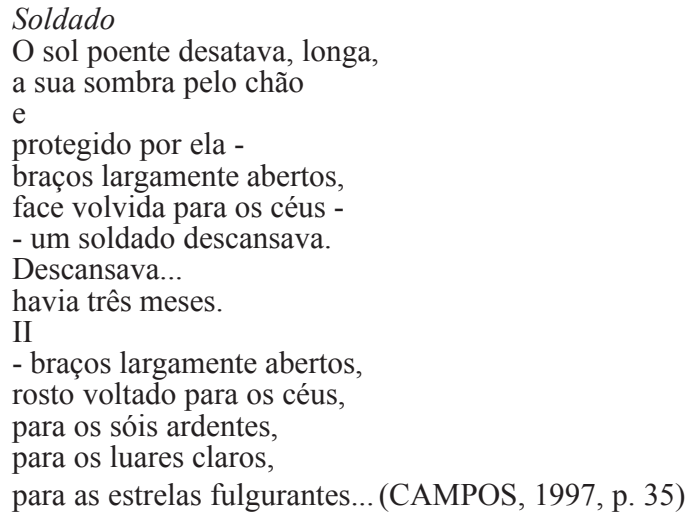

A transposição para uma forma versificada, igualmente aqui, faz ressaltar o ritmo, além de evidenciar a visualidade da cena, dando força à figura humana. A repetição da frase/verso que introduz o soldado no contexto é de extrema importância. Por isso, no fecho do parágrafo/poema, o aniquilamento introduzido ao referir que este homem estava morto, eclipsa-se totalmente, dando lugar à vida de um "rosto voltado para os céus, para os sóis ardentes, para os luares claros, para as estrelas fulgurantes..." Assim, a plasticidade da figura humana se impõe ao leitor, que, com esta repetição, pode compor uma imagem nítida do soldado.

O corpo morto - captado pelo poeta com extrema sensibilidade - 
transforma-se, para o cientista, em "aparelho" que lhe possibilita medir o ar. $\mathrm{O}$ exame atento permite-lhe perceber a forma intacta, a conservação dos traços e, principalmente, a ausência de vermes. O corpo, mumificado, não fora decomposto. Este "aparelho" the possibilita constatar a "secura extrema dos ares" (CUNHA, 1985, p. 112). A mesma particularidade é encontrada nos cavalos mortos, "espécimes empalhados de museus" (CUNHA, 1985, p. 112): não sujeitos à putrefação, têm uma "aparência de vida" (CUNHA, 1985, p. 113). Os corpos mortos - do soldado e dos animais - cumprem a função de higrômetros. Ora, "higrômetros singulares" é o título conferido à seção. Desta forma, embora, no decorrer da cena, os termos científicos não estejam presentes - ele utiliza apenas o vocábulo "aparelhos" -, o olhar do cientista preside a descrição, seja na observação minuciosa da natureza, seja no exame dos corpos. A aliança entre "ciência e arte" domina o quadro: poeta e cientista mantém entre si um diálogo equânime.

Em algumas ocasiões, ao acercar-se do novo, o cientista desaparece quase completamente e o poeta tem primazia. Seduzido pela realidade objetiva, o ver desencadeia ilusão. Esta, provocada pela aparência do objeto, a ele está intimamente associada. Não raro, porém, a ilusão do real atinge níveis mais profundos: "consiste em relegar o real a um outro mundo, completamente distinto do mundo da aparência" ${ }^{17}$. Este olhar de fora, transforma-se em olhar fantasmático. Neste momento, o real funciona apenas como o ponto de partida para o emergir dos fantasmas. Enquanto na comparação o objeto ainda está presente, no olhar fantasmático ele desaparece, para fazer eclodir um mundo ilusório, apenas entrevisto pelo sujeito. Prevalece, agora, não mais a tentativa de ver uma realidade, mas de mostrar o que o viajante vê a partir da realidade. Nesta perspectiva, talvez a cena culminante seja a que tem lugar "no topo da Favela", quando ao viajante impõese a ilusão do mar. Os "fenômenos óticos bizarros" derivam de uma natureza submetida a condições especiais; o cientista explica: "se a prumo dardejava o sol e a atmosfera estagnada imobilizava a natureza em torno, atentando-se para os descampados ao longe, não se distinguia o solo" (CUNHA, 1985, p. 113).

Sob tal influxo, ao olhar, o viajante não vê mais o "agreste": a imagem do mar substitui a realidade objetiva. Fascinado, a ilusão o domina: "Então, ao norte da Canabrava, numa enorme expansão dos plainos perturbados, via-se um ondular estonteador; estranho palpitar de vagas longín-

${ }^{17}$ No original: "consiste à reléguer le réel dans un autre monde complètement distinct du monde de l'apparence." (ROSSET, 1984, p. 70). A discussão de Rosset está baseada em Hegel, que estabelece duas formas de ilusão: a ilusão grosseira e a ilusão metafísica. 
quas; a ilusão maravilhosa de um seio de mar, largo, irisado, sobre que caísse e refrangesse, e ressaltasse a luz esparsa em cintilações ofuscantes..." (CUNHA, 1985, p. 113)

O sertão - realidade objetiva - desdobra-se na ilusão do "seio de mar", projeção fantasmática' ${ }^{18}$ de um olhar seduzido: "Quem quer que esteja fascinado, pode-se dizer dele que não enxerga nenhum objeto real, nenhuma figura real, pois o que vê não pertence ao mundo da realidade mas ao meio indeterminado da fascinação" (BLANCHOT, 1987, p. 23). O mar - imagem ausente - ilumina-se; presentifica-se no movimento ilusório de um olhar sob o influxo do fascínio.

Ao comprazer-se com o que vê, o viajante de Os sertões afasta-se dos outros viajantes naturalistas, que não se deixam seduzir. "Aliás, se porventura, os exploradores se deixam algumas vezes levar por um local especialmente agradável, algo parece interferir de imediato - um ruído, um perigo, um espécime novo qualquer - e remetê-los à sua atividade prínceps. Ao seu posto de observação" (SÜSSEKIND, 1990, p. 109). Spix e Martius, ao constatarem um "fenômeno maravilhoso", não se deleitam com o objeto da visão. Ao contrário, procuram cumprir o papel de cientistas medindo-o com os instrumentos de que dispõem. Na narrativa euclidiana, embora o cientista faça a advertência para os "fenômenos óticos bizarros" e explique as condições em que aparecem, ele se deixa levar pela sedução, possibilitando a irrupção do olhar fantasmático.

Uma última característica, comum às narrativas de viagem, é a busca da verdade. Também em Os sertões este traço está presente, aproximando-o dos textos dos viajantes naturalistas. No entanto, ao contrário das narrativas de viagem, a questão não está tematizada. Enquanto Neuwied e Spix e Martius reportam-se à necessidade de as descrições corresponderem à realidade, Euclides procura mostrar as condições específicas em que realizou a travessia:

O que se segue são vagas conjeturas. Atravessamo-lo no prelúdio de um estio ardente e, vendo-o apenas nessas quadra, vimo-lo sob o pior aspecto. O que escrevemos tem o traço defeituoso dessa impressão isolada, desfavorecida, ademais, por um meio contraposto à serenidade do pensamento, tolhido pelas emoções da guerra. Além disto os dados de um termômetro único e de um aneróide suspeito, misérrimo arsenal científico com que ali lidamos, nem mesmo vagos lineamentos darão de climas que divergem segundo as menores disposições topográficas, criando aspectos dispares entre lugares limítrofes. (CUNHA, 1985, p. 110)

${ }^{18}$ FACIOLI, analisando a cena, afirma que ela está sob o influxo das "leis do delírio", "as quais como que programam o sujeito de uma forma radical para aproximá-lo do objeto segundo a determinação deste." (FACIOLI, 1990, p. 144). 
Sujeito às "emoções da guerra", suas informações são passíveis de falhas. Se o trecho mostra que a investigação pode não corresponder à realidade de forma incontestável, também deixa inequívoco o seu desejo de com ela estar em sintonia. Afirmando que suas reflexões são "vagas conjeturas", ele se resguarda contra equívocos e preserva o ideal de verdade, tão caro aos viajantes naturalistas.

Na discussão sobre o narrador-viajante de "A terra", surpreende o diálogo com as narrativas de viajantes naturalistas do século XIX. Alguns aspectos, nelas predominantes, estão presentes no texto de Euclides. Mesmo quando delas se afasta, não deixam de ser referência obrigatória. Realizar a travessia - dificultada pelos obstáculos que se interpõem - significa estar atento ao desvelamento das múltiplas faces do sertão. O estranhamento marca a viagem. Ao longo do percurso, o viajante, é o observador que identifica, cataloga e descreve o objeto. Olhar significa atividade; ao ver, submete o objeto à investigação, buscando aproximá-lo da realidade. Ao descobri-lo é sempre o olhar do "estrangeiro", com sua bagagem cultural, que o descobre. No entanto, muitas vezes, ao iluminar o objeto o encobre, por fazer presente um mundo ausente. É o fascínio que estimula este olhar: o viajante é o outro seduzido pelo novo que o sertão representa.

\section{O OLHAR DOS EXPEDICIONARIOS}

O olhar do viajante é o olhar de quem se depara com o desconhecido, constituindo-se, por isso mesmo, em um olhar de estrangeiro. Percorrer o sertão é defrontar uma realidade nova. Para acercá-la impõe-se o arsenal de imagens pertencentes ao mundo civilizado. O olhar primeiro sobre o sertão é, pois, o de alguém que é oriundo de um outro espaço. $\mathrm{O}$ viajante é um dos diversos prismas a que o narrador recorre para ver o sertão como alteridade. Os outros são representados pelos olhares dos expedicionários, também eles viajantes. Estes, no entanto, não são atraídos pelo novo que o sertão representa: ao adentrarem esta "terra ignota" as marcas da guerra se sobressaem. Entre eles destacam-se: o olhar dos soldados feridos que retornam - "o refluxo da campanha" (CUNHA, 1985, p. 462) -, o olhar da divisão salvadora e o olhar da comitiva do ministro da guerra. O sertão é visto sob enfoques diferentes, conforme a experiência de cada um desses grupos. As trilhas percorridas por estes viajantes aparecem agora sobredeterminadas pelos fatos históricos.

Para o soldado ferido que retorna do campo de batalha o sertão já não se apresenta como o desconhecido. Ao olhar, as lembranças assomam para povoar o espaço de novos significados. Ao rever as mesmas paragens já não é mais o entusiasta, esperançoso da vitória, que as percorrera antes; agora, a desilusão da conquista não realizada, torna a travessia mais difícil: 
Ali estava a mesma trilha que um mês antes haviam percorrido, impávidos ante quaisquer recontros com o adversário esquivo, fascinados pelo irradiar de quatro mil baionetas, sacudidos no ritmo febricitante das cargas. Parecia-lhes agora mais áspera e impraticável - coleando em curvas sucessivas, tombando em ladeiras resvalantes, empinando-se em cerros, tornejando encostas, insinuando-se, impacta, entre montanhas. (CUNHA, 1985, p. 464)

O narrador persegue a trajetória do soldado ferido. É da sua perspectiva que narra. É a partir de seu olhar que abarca os "trechos memoráveis" (CUNHA, 1985, p. 318). É a sua emoção diante do que vê que revela. Seguindo-o de perto, mostra as recordações que o assolam ao se deparar com determinados lugares:

Nas cercanias de Umburanas, o casebre estruído, onde os sertanejos, de tocaia, tinham aferrado de um choque o grande comboio da expedição Artur Oscar; além das Baixas, as margens do caminho debruando-se de ossadas brancas, adrede dispostas numa encenação cruel - recordavam o morticínio de março; numa inflexão antes do Angico, o ponto em que Salomão da Rocha alteara, por minutos, diante da onda rugidora que vinha em cima da expedição Moreira César, a barragem de aço de suas divisões de artilharia; no córrego seco, mais longe, a ribanceira a pique em que tombara do cavalo, pesadamente, morto, o coronel Tamarindo; (CUNHA, 1985, p. 464)

A viagem de retorno está marcada quer pela própria experiência, quer pelos acontecimentos relativos à expedição anterior. O soldado olha para um sertão estigmatizado pela guerra, cuja travessia traz à memória um passado recente. Este olhar, embora ainda um olhar de "estrangeiro", é completamente diferente daquele do viajante; ele vê um sertão constituído pelos significados dos fatos históricos, o que não ocorria com o viajante, que o afrontava com o estranhamento de quem se depara com o novo.

A "Divisão Salvadora" (CUNHA, 1985, p. 492) também representa um olhar de "estrangeiro"; o narrador acompanha o seu percurso desde Queimadas até a chegada ao arraial. Da mesma forma que os soldados feridos, tem seu olhar atraído por aqueles aspectos do sertão que sinalizam a guerra. Igualmente, para ela, ver o sertão é recordar. Aqui a recordação refere-se unicamente aos fatos históricos vividos pelas expedições anteriores. Em Queimadas, o "prolongamento do largo aberto para a caatinga" (CUNHA, 1985, p. 495) logo suscita a alusão histórica:

Naquele chão batido dos rastros de dez mil homens, haviam turbilhonado na vozeria dos bivaques - paixões, ansiedades, esperanças, desalentos indescritíveis.

Transposta acessível ondulação, via-se, recortando o cerrado dos arbustos, um sulco largo de roçada, retilíneo e longo, que um alvo extremava - a linha de tiro, onde se exercitara a divisão Artur Oscar. (CUNHA, 1985, p. 495-6). 
Ao estranhamento espacial, básico no olhar do viajante, o olhar dos "novos expedicionários" (CUNHA, 1985, p. 496) acrescenta um dado novo: o estranhamento social. A percepção da diversidade de linguagem, hábitos e pessoas, induz o sentimento de estarem adentrando em "território estrangeiro" (CUNHA, 1985, p. 496). Por outro lado, na viagem, prepondera o temor de não terem oportunidade de entrarem na luta; o desejo de demonstrarem o heroísmo é constantemente ressaltado. As emoções da viagem recebem um enfoque especial, em detrimento das imagens do sertão. A visão do arraial em ruínas denuncia que finalmente alcançaram o objetivo. Ao se depararem com o acampamento são os olhares destes expedicionários que assumem o primeiro plano. A surpresa diante da realidade, derivada da frustração das expectativas, desencadeia a visão do objeto: "Tinha-se a impressão de chegar a um lugarejo suspeito dos sertões” (CUNHA, 1985, p. 514). É só alguém vindo de fora que pode ver o acampamento sob a perspectiva do estranhamento.

O olhar destes "novos expedicionários" é sobremaneira atraído pelas imagens da guerra em detrimento das imagens do sertão. Inicialmente, elas ainda estão presentes, mas apenas como elemento desencadeador de lembranças. No decorrer da viagem, destaque é dado à "impaciência heróica" (CUNHA, 1985, p. 514) destes lutadores, cujo desejo é de chegarem a tempo de "compartir as glorificações do triunfo" (CUNHA, 1985). Finalmente, são atraídos apenas por aspectos relativos à guerra, estando em primeiro plano o anseio de entrarem na luta.

A comitiva do ministro da guerra, da mesma forma que os outros, revela-se uma perspectiva interessante. Sob esse olhar, novamente as imagens do sertão conjugam-se com as imagens da guerra. A comitiva, embora "bem montada e abastecida" (CUNHA, 1985, p. 500), ao enfrentar a "trilha poenta, desesperadamente torcida em voltas infinitas, retalhando-se em desvios" (CUNHA, 1985, p. 501), não se exime das fadigas impostas pela difícil travessia. Na viagem, com o itinerário marcado pela passagem por diversos locais - "Contendas", "Tanquinho", "Cansação" - os sinais da guerra se presentificam a cada momento, seja no constante encontro com os feridos, seja nos protestos escritos nos casebres. A percepção destas crônicas se mostra o elemento mais importante deste olhar. Nelas se exibe um aspecto importante da guerra: a frustração dos soldados. Não mais o desejo de manifestar o heroísmo e o temor de não haver tempo de fazê-lo: nelas se inscreve o reverso da campanha "libelos brutos, sem uma frase varonil e digna" (CUNHA, 1985, p. 502). É na perspectiva deste olhar que se sobressai a desilusão daqueles que, já tendo participado do conflito, feridos, se viram dele alijados. Este olhar está em sintonia com o do soldado ferido; suas decepções são apreendidas, porém, agora, sob o prisma da comitiva. 


\section{BIBLIOGRAFIA}

ALENCAR, José de. O sertanejo. São Paulo, Edição Saraiva, 1962. 2 v. BÍBLIA de Jerusalém. São Paulo, Paulinas, 1991.

BLANCHOT, Maurice. O espaço literário. Rio de Janeiro, Rocco, 1987. p. 23.

CAMINHA, Pero Vaz. Carta. In: CASTRO, Silvio. A carta de Pero Vaz de Caminha. Porto Alegre, LP\&M, 1996.

CARDOSO, Sérgio. O olhar do viajante (do etnólogo). In: NOVAES, Adauto (Org.). O olhar. São Paulo, Companhia das Letras, 1988.

CAMPOS, Augusto de. Transertões. In: CAMPOS, Augusto de, CAMPOS, Haroldo de. Os sertões dos campos: duas vezes Euclides. Rio de Janeiro, Sette Letras, 1997.

CHEVALIER, Jean, GHEERBRANT, Alain. Dicionário de símbolos. Rio de Janeiro, José Olympio, 1990.

CIRLOT, Juan-Eduardo. Dicionário de símbolos. São Paulo, Editora Moraes, 1984.

CRISTÓVÃO, Fernando. A transfiguração da realidade sertaneja e a sua passagem a mito. Revista USP, n. 20, dez. jan. fev. 93-94.

CUNHA, Antônio Geraldo. Dicionário etimológico Nova Fronteira. Rio de Janeiro, Nova Fronteira, 1996.

CUNHA, Euclides da. Os sertões. Ed. crítica organizada por Walnice Nogueira Galvão. São Paulo, Brasiliense, 1985.

CUNHA, Euclides da. Obra completa. Rio de Janeiro, Nova Aguilar, 1995. v. 1: Contrastes e confrontos.

CURTIUS, Ernst Robert. Literatura Européia e Idade Média Latina. São Paulo, Hucitec, EDUSP, 1996.

FACIOLI, Valentim. Euclides da Cunha: a gênese da forma. São Paulo, 1990. Tese (Doutorado em Letras) - Faculdade de Filosofia, Letras e Ciências Humanas, Universidade de São Paulo, 1990.

FARIA, Ernesto. Dicionário escolar latino-português. Rio de Janeiro, FENAME, 1975.

FARIA, João Roberto. Os sertões: um livro vingador. In: BRAIT, Beth (Org.). O sertão e Os sertões. São Paulo, Arte \& Ciência, 1998.

FERNANDES, Ana. O Outro que somos nós na "Carta" de Pêro Vaz de Caminha. In: FALCÃO, Ana Margarida; NASCIMENTO, Maria Teresa; LEAL, Maria Luísa (Orgs.). Literatura de viagem: narrativa, história, mito. Lisboa, Edições Cosmos, 1977.

GALVÃO, Walnice Nogueira, GALOTTI, Oswaldo (Orgs.). Correspondência de Euclides da Cunha. São Paulo, EDUSP, 1997. 
GOMES, Gínia Maria. A travessia de uma "terra ignota": leitura de Os sertões, de Euclides da Cunha. Porto Alegre, 1990 Tese (Doutorado em Literatura Brasileira) - Programa de Pós-Graduação em Letras, Universidade Federal do Rio Grande do Sul, 1999.

GUIMARÃES, Bernardo. O ermitão de Muquém. São Paulo, Livraria Martins Editora, 1952.

HOLANDA, Sérgio Buarque de. Visão do paraíso: os motivos edênicos no descobrimento e colonização do Brasil. São Paulo, Brasiliense, 1994.

KRYSINSKI, Wladimir. Discours de voyage et sens de l'altérité. In: SEIXO, Maria Alzira. A viagem na literatura. Lisboa, Europa-América, 1997.

LÉON-DUFOUR, Xavier (Org.). Vocabulário de teologia bíblica. Petrópolis, Vozes, 1992.

OLIVEIRA, Franklin de. O cabeleira. Rio de Janeiro, Edições de Ouro, 1969.

PAIVA, Manuel de Oliveira. Dona Guidinha do Poço. Rio de Janeiro, Edições de Ouro, 1965.

PIMENTEL, Maria do Rosário e SANTOS, Maria do Rosário Laureano. O real no jogo de espelhos da literatura de viagens no século XVI. In: FALCÃO, NASCIMENTO, LEAL. Literatura de viagem: narrativa, história, mito. Lisboa, Edições Cosmos, 1977.

ROLAND, Ana Maria. Fronteiras da palavra, fronteiras da história. Brasília, Editora da Universidade de Brasília, 1997.

ROSSET, Clément. Le réel et son double. Essai sur l"illusion. Paris, Gallimard, 1984.

SPIX, MARTIUS. Viagem pelo Brasil (1817-1820). São Paulo, Melhoramentos, [19-]. v. 2.

SÜSSEKIND. O Brasil não é longe daqui. São Paulo, Companhia das Letras, 1990. 